The Monstrosity of Matter in Motion: Galileo, Descartes, and Hobbes's Political Epistemology

Andrea Bardin

The change-over from a developmental to a static conception of matter was as profound as the change from a geocentric to a heliocentric astronomy, and its effects were as far reaching.

Stephen Toulmin, The Architecture of Matter

\title{
Introduction
}

The seventeenth century, the century of the scientific revolution, was populated by monsters, monsters that the new mechanical science was challenging, and also monsters that it had a part in generating. Descartes's and Hobbes's philosophical systems played a key role in providing a metaphysical foundation to the new science of motion both in the natural and in the political domain. Focusing on the monstrosity of 'matter in motion', my aim is to suggest that their philosophical efforts, although apparently opposed, shared the same ideological reaction to the monstrous contingency of 'matter' evidenced by the experimental practices carried on during the first half of the century in both natural philosophy and the English Civil War.

As the Aristotelian world picture collapsed, the concepts of matter and motion underwent a process of reduction to mathematical description and to physical explanation which eventually resulted in what was later canonised - after Newton - as classical mechanics. In this process 'matter in motion' assumed ambivalent meanings: on the one hand it named extension and body, the abstract object of the new natural philosophy; on the other hand it named what resisted, at different levels and in different domains, this very process of reduction. In natural philosophy Descartes's institution of Reason as a disembodied subject dominated the whole process. In political theory it was Hobbes who opposed the artificial 
unity of the body politic represented by the sovereign to the material multiplicity of the multitude living in the state of nature. Connecting Descartes's and Hobbes's enterprises will make it possible to explain how the struggle carried on by early modern mechanical philosophy against the monstrosity of matter in motion generated epistemological monsters in the domains of both the natural and the civil sciences.

The main 'conceptual characters' of the present narration are Galileo, Descartes and Hobbes. They play the following roles: 1) Galileo poses the problems of the ontological status of matter and of the relativity of motion; 2) Descartes solves both problems with a single metaphysical move; 3) Hobbes transfers both Galileo's problems and Descartes's solution into the domain of political philosophy. ${ }^{1}$ This path is intended to clarify in which sense Hobbes's peculiar form of radical materialism was in fact a surreptitious reduction of materialism to its ideological counterpart: Cartesian dualism. If his political project developed a disciplinary reduction of human matter to the artificial functioning of a wellordered body politic, this was not at all peculiar to Hobbes's own materialistic project: it was rather early modern mechanical philosophy itself that entailed such a political-pedagogical project.

\section{Galileo: The Epistemological Problem}

To begin, I will focus on two crucial aspects of the same problem emerging from Galileo's scientific research, one strictly ontological, the other epistemological. The two aspects concern respectively the object and the subject of the new emerging science.

\footnotetext{
${ }^{1}$ Quotations from Galileo, Descartes and Hobbes refer to collected works according to the following abbreviations: Le Opere di Galileo Galilei, Edizione Nazionale, ed. A. Favaro, 20 vols., Firenze: Barbera, 1964-68 [GG]; Euvres de Descartes, eds. C. Adam and P. Tannery, 12 vols., Paris, 1897-1913 (J. Cottingham et al., trans., The Philosophical Writings of Descartes, 3 vols. Cambridge University Press, 1985-91) [AT]; English Works of Thomas Hobbes of Malesbury, ed. Sir W. Molesworth, 11 vols., London, 1839-45 [EW]; Thomae Hobbes malmesburiensis opera philosophica quae latinae scripsit omnia, ed. Sir W. Molesworth, 5 vols., London, 1839-45 [OL]. Translations from Latin, Italian and French can differ from the English versions I refer to, according to my interpretation and on my responsibility.
} 
It is commonly assumed that Galileo's overall project was - as he pictured it in Il saggiatore - to read the "book of nature", which

is written in mathematical language, and the symbols are triangles, circles and other geometrical figures, without the help of which it is humanly impossible to comprehend a single word of it, and one wanders in vain through a dark labyrinth. (GG VI, 232)

The argument is quite clear, mathematics is the code for the understanding of nature precisely because nature itself has been created geometrical. But the project thus displayed remained in Galileo's works scarcely more than a metaphor: although it can be considered a kind of postulate, or at least the horizon of Galileo's research, it was not at all its achievement. ${ }^{2}$ On the contrary, it posed a set of problems that strongly contributed to dictating the physical and philosophical agenda of the seventeenth century. I am now going to briefly sketch two of these problems that are crucial for my argument: the problems of a) the contingency of matter in motion and b) the relativity of its knowledge.

a) Galileo soon became aware of the threatening monstrosity of matter. In a 1602 letter to Guidobaldo Del Monte he posed the problem, as usual, in a quite 'practical' way, as a problem of measurement:

As far as matter is concerned, its contingency affects the abstract propositions of the geometer; and being these [propositions] so distorted that no perfect science is thus possible, therefore the mathematician is relieved from considering them. (GG X, 100)

According to Galileo the very nature of matter in motion resists measurement; it is not easily reducible to a geometrical account, that is to science. And the problem is even worsened by a further complication emerging from the astronomical discoveries of Copernicus, the problem

\footnotetext{
${ }^{2}$ The image of the book of nature was not Galileo's invention (it was rather a quite common topos of the Humanistic polemics against Scholasticism), and for many reasons his work lacks any metaphysical systematisation of his actual achievements. But through the mediating figure of Mersenne (and then of Descartes, of course), his research was the starting point of mechanical philosophy: the systematic analysis of the metaphysical, epistemological, ontological and, as I am going to stress, political implications of the new world picture.
} 
of the relativity of the point of view, which can be summarised as follows: How can one measure motion while moving?

b) In fact the attack on the Ptolemaic-Aristotelian earth-centred worldview does not appear to have been the most challenging novelty advanced by the Copernican revolution. This attack, in itself, did not revive the spectre of relativity that had been exorcised for centuries by Christian philosophy: the Copernican revolution certainly deprived humans of their narcissistic primacy at the centre of the universe (on earth), but it still allowed a godlike sun to be another sufficiently glorious centre. More seriously, it was the new Galilean concept of the relativity of motion that ruined the keystone of the entire monument represented by the Aristotelian physics of motion, where an absolute high and low existed along with the natural tendency of the four elements to spontaneously reach their natural places. ${ }^{3}$ For the Galilean physics of motion the basic assumption was rather that anything was moving, and on this (quite instable) ground a new conception of the relativity of motion was growing, that eventually deprived the universe of a definitive reference frame.

From a mathematical point of view the problem of the measurement of motion could be solved with a quite simple transformation, called - even though it was not Galileo's invention - the "Galilean transformation". ${ }^{4}$ But if we consider its physical implications, this solution completely invalidated the Aristotelian conception of a qualitatively hierarchised cosmos. Furthermore, as a purely mathematical description, Galileo's kinematic account of the

\footnotetext{
${ }^{3}$ Aristotle had won for centuries the battle against the 'physical' relativism of atomists, thanks to physical arguments, by anchoring space coordinates to an absolute point of view and cancelling chance from motion: "Nor do such distinctions (up and down and right and left) hold only in relation to us. To us they are not always the same but change with the direction in which we are turned [...]. But in nature each is distinct, taken apart by itself. It is not every chance direction which is up, but where fire and what is light are carried; similarly, too, down is not any chance direction but where what has weight and what is made of earth are carried." Aristotle, Physics, IV.1, 208b9-26, in The Complete Works of Aristotle, ed. J. Barnes (Princeton University Press, 1991), vol. I, 50.

${ }^{4}$ The scientific concept of Galilean relativity does not match Galileo's conception of the relativity of motion, which cannot be considered a 'principle' of his physics, in fact still earth-centred and linked to a quasi-Aristotelian conception of free-fall and the 'nature' of heavy bodies. A. Chalmers, "Galilean Relativity and Galileo's Relativity," in Correspondence, Invariance and Heuristics. Essays in Honour of Heinz Post, ed. S. French and H. Kamminga (Dordrecht: Kluwer Academic Publishers, 1993), 200-201. Today, 'Galilean relativity', or 'invariance', also named 'Newtonian relativity', refers a threedimensional 'Cartesian' coordinate system (not Descartes's invention either) which makes it possible to calculate speed in relation to the chosen reference frame.
} 
relativity of local motion was contributing to making the former world picture collapse without providing an alternative one. This process was bringing about a new picture of the universe as lacking any centre at all (a quite dangerous picture indeed - as Bruno had personally experienced just a few years before). In fact, the lack of a physical explanation of the causes of motion elicited a remarkable philosophical effort, which eventually paved the way for a new conception of matter in motion and, in the long term, for the mechanical world picture.

For many reasons Galileo did not intend to make such an effort. And yet, as the new science of matter in motion became a shared 'reference frame' in Europe, a metaphysical goal was assumed by all those who intended to build a philosophical system out of Galileo's mechanics, and in particular - what I am now concerned with - by those who were part of Mersenne's circle, Descartes and Hobbes included.

\section{Descartes: The Epistemological-Metaphysical Solution}

Descartes's solution followed many years of work on optics, geometry, and various kinds of physical and physiological phenomena, not to mention all the ruminating around the legitimation of this work through what is probably better known today as Descartes's 'philosophy'. ${ }^{5}$ The structure of Descartes's solution to the problem posed by Galileo was quite simple. He grounded the new science of matter in motion on metaphysical dualism: on the one hand res extensa, i.e. the moving bodies with measurable primary qualities; on the other hand res cogitans, i.e. an eternal non-moving Reason concerned with ideas matching

\footnotetext{
${ }^{5}$ Most of what Descartes conceived as his truly philosophical enterprise, his 'natural philosophy', now simply appears as some odd old science, while his reflection concerning the grounds of this research, namely the sole introduction to the Discourse on the Method and the Meditations, is commonly considered the apex of his philosophy. This is an ideological effect he himself helped to generate: the separation of science and philosophy, a separation that made of both a kind of selfreferential field of research, on the basis of the metaphysical separation of the domains of human thought and matter, or liberty and necessity, or any of the dualisms grounded on the belief that the 'human' is an exception to the domain of nature - in Spinoza's words an "imperium in imperio".
} 
the primary qualities of bodies. The second founded the knowledge of the first. In this sense Descartes's metaphysical dualism not only was 'theologically correct', it was primarily part of a project of progressive clarification of the central notions of mechanics. It entailed a redefinition of the epistemological status of the neutralized gaze of the subject of science and, at the same time, of its object, matter in motion.

Since Galileo's inertial framework had introduced a fundamental indistinction between rest and motion, the path towards Newton's identification of the "Innate Force of Matter" with the essentially passive nature of matter was opened. The vis inertiae was eventually reduced by Newton to a "force of inactivity" characterising a matter whose main feature was in fact the “inactivity of the Mass." ${ }^{\prime 6}$ Drawing on Beckham's 'principle of perseverance', Descartes played an important role in this process of reducing matter to a passive supporting role in the Galilean conception of the relativity of motion. Along this path Descartes transformed matter into a unique, liquid-like and passive substance, independent of motion and presenting no trace of physical void: 'body' or 'extension', i.e. the metaphysical object of mechanics.

On the other hand motion, completely purified from matter, was reduced to "nothing but a mode of the matter which is moved" (AT VIII, 61). Because it was a basic explanatory notion in mechanics, motion had to obey to laws which had to be invariant, thus overcoming the lack of foundation in the researches of Galileo who, "not considering the first causes of nature, has only sought to the reasons of some particular effects, and thus he has built without foundation" (AT II, 380). ${ }^{7}$ For this purpose Descartes eliminated any "arbitrariness in the distinction between rest and motion" 8 by introducing the possibility of an absolute measurement of motion, grounded on an external non-moving point of view where the

\footnotetext{
${ }^{6}$ I. Newton, Philosophiae Naturalis Principia Mathematica (London: Jussu Societatis Regiæ ac Typis Josephi Streater, 1687), 2-3. See W. Hooper, "Inertial Problems in Galileo's Preinertial Framework," in The Cambridge Companion to Galileo, ed. P. Machamer (Cambridge University Press, 1998), 170-171.

${ }^{7}$ Furthermore: "Everything he says about the speeds of bodies descending in the void, etc., is built without foundation" (AT II, 385).

${ }^{8}$ D. Garber, "Descartes's Physics," in The Cambridge Companion to Descartes, ed. J. Cottingham (Cambridge University Press, 1992), 307.
} 
ultimate cause of motion resided too, the res cogitans. As a general and perpetual 'cause' of motion, God's immaterial eternity coincided thus with the subject of knowledge of a clockwork universe deprived of any qualities and therefore perfectly suitable for a perfect geometrical description, in which only human reason was allowed to participate.

In short, it was only after Descartes had eventually identified matter with 'extension', i.e. the metaphysical object of mechanics, that he was allowed to commit motion, completely purified from matter, to God's ruling power, i.e. to the metaphysical subject of mechanics. In effect, it was far before writing his Discourse on the Method that, in a famous letter to Mersenne in 1630, Descartes had explicitly identified God's "mathematical truths" and the laws of nature:

In my treatise on physics I shall not avoid discussing a number of metaphysical topics, and especially the following: the mathematical truths which you call eternal have been laid down by God and depend on him entirely no less than the rest of his creatures [...]. Please do not hesitate to assert and proclaim everywhere that it is God who has laid down these laws [mathematical truths] in nature just as a King lays down laws in his Kingdom. (AT I, 145)

In fact, this was not even Descartes's invention. A few years before, Francis Bacon, to whom Hobbes was for a long time the secretary, wrote, referring to James I:

Kings ruled by their laws as God did by the laws of nature, and ought as rarely to put in use their supreme prerogative as God doth his power of working miracles. ${ }^{9}$

This passage is quite emblematic of the fact that the 'laws of nature' were first born a theological-juridical concept, which later applied to natural philosophy through the mediation

\footnotetext{
${ }^{9}$ F. Bacon, The Works of Francis Bacon, ed. J. Spedding et al. (London, 1879), vol. I, 175.
} 
of the theological assumption of God as the sovereign of the universe. ${ }^{10}$ What is more pertinent to my argument, through the 'laws of nature' plus the assumption of the disembodied look of a God-like reason, Descartes's natural philosophy was thus able to explain the motion of matter independently of any moving and relative point of view. The perfect correspondence between the principles of geometry and the laws of nature was perfectly clear to the intuitive faculty of a self-transparent subject of science, and the mechanical motion of matter - entirely reduced to body or extension - was suitable for a complete account made through the formalised language of geometry.

\section{Hobbes: A Political Epistemology}

Like all the philosophers connected to Mersenne, Hobbes was deeply involved in contributing to the foundation of the new mechanical philosophy. But since the beginning he committed it to "unlock[ing] the secrets of matter and motion" without referring to any transcendental principle, and radically opposed Descartes's dualism. It is quite interesting to note that Hobbes's account of the journey in Europe on which he accompanied the young Sir Cavendish in his grand tour in 1634, starts precisely taking the 'Galilean' image of the book for what it is - i.e. a metaphor ("But we did not spend all this time with books, unless you could say the world was like a book") - and clearly remarking that in nature there is "nothing but motion" (OL I, LXXXIX-XC). And yet at the beginning of the 1640s, through the clash

\footnotetext{
${ }^{10}$ The commonly accepted opposition between nomos and physis, and the idea itself of a law (nomos) governing an 'organic' nature (physis) was completely nonsense for the Greeks, and such it remained as long as the Aristotelian framework resisted - except for the reference to a moral 'law of human nature' which, on the contrary, went back to to the Stoics and was widely re-elaborated by Thomas Aquinas. In general, although during the first part of the seventeenth century the use of the word 'law' referring to natural regularities was still quite rare, "the idea of nature being governed by laws had become widely acceptable." J. R. Milton, "Natural Law," in The Cambridge History of Seventeenth-Century Philosophy, ed. D. Garber and M. Ayers (Cambridge University Press, 1998), 684. Yet in Francis Bacon the emerging physical meaning of the concept of 'law' was superposed, although often inconsistently, to the concept of 'form' or formal cause, i.e. a concept still permeated by Aristotelianism (Milton, "Natural Law," 680-81; 685-86), and even Galileo and Mersenne did not speak of laws governing the regularities they discovered in nature. It was only Descartes who officially started a 'technical' use of the term by referring in Principia Philosophiae (1644) to the fundamental principles of motion as "rules, i.e. laws of nature", whose knowledge was founded on God's immutability (AT VIII, 62). See S. Roux, "Les lois de la nature au XVII ${ }^{\text {ème }}$ siècle: le problème terminologique," Revue de Synthèse 122 (2009): 55 ff.
} 
with Descartes's metaphysics, and the disputes they had on optics and geometry, an epistemological problem concerning the stability of science was posed that, from a materialist perspective, could not be easily solved by referring to the transcendence of reason. ${ }^{11}$

The structure of the problem was quite simple: with no res cogitans the subject of science is by definition in motion; therefore no absolute point of view on matter in motion can be assumed. Furthermore, within a mathematical framework the problem of the resistance of matter to a geometrical account cannot be easily solved through a straightforward reference to some kind of divine legislation. And, just to complicate the whole thing, Hobbes was determined to extended mechanics to the political field where, as in morality, Descartes's metaphysics explicitly denied any possible application of mechanics, because res cogitans was supposed to introduce an unpredictable element of liberty in the bodily motion characterising the mechanical-physiological functioning of human passions.

Hobbes's search for a solution to this set of problems touched, of course, both the subject and the object of his monistic and materialistic version of mechanical philosophy. ${ }^{12}$ And this also in the field of civil science, where he had two connected aims: a) to build a point of view internal to matter in motion, but - as far as possible - immune from motion; and b) to provide an account of local motion that would reduce the monstrous contingency (and therefore the threatening unpredictability) of matter in motion to geometrical order.

\footnotetext{
${ }^{11}$ Hobbes fled to Paris at the beginning of the 1640s, where he remained in self-exile until 1651 . The issue of Descartes's influence on Hobbes's philosophy goes back at least as far as G. Croom Robertson, Hobbes (London, 1886), and was particularly developed in F. Brandt, Thomas Hobbes's Mechanical Conception of Nature (Copenhagen: Leven and Munksgard, 1928). Although it has undergone further and interesting developments, this field of research tends to remain especially bound to the analyses of Hobbes's natural philosophy, and opposed to the thesis of a Baconian influence, according to the schematic opposition of rationalism and empiricism. In fact this apparent alternative touches the core of the relationship between Hobbes's natural and civil philosophy. More recently, other paths have been covered concerning the influences of the Latin classics and of Aristotle, respectively in Q. Skinner, Reason and Rhetoric in the Philosophy of Hobbes (Cambridge University Press, 1996), and C. Leijenhorst, The Mechanisation of Aristotelianism: The Late Aristotelian Setting of Thomas Hobbes' Natural Philosophy (Leiden: Brill, 2002). I believe what Sorell named "the old question called 'Hobbes's system'" should not force the choice of any single alternative, but rather should encourage exploration of all the different paths in search of Hobbes's originality in both the natural and civil sciences. See T. Sorell, "Hobbes's Scheme of the Sciences," in The Cambridge Companion to Hobbes, ed. Id. (Cambridge University Press, 1996), 45. For this purpose I am developing here a theme connected to the Galilean and Cartesian influence, trying to show that it concerned all the domains of Hobbes's research.

${ }^{12}$ For a synthetic attempt to provide such a consistent picture of Hobbes's materialism, see P. Machamer, "Thomas Hobbes," Hobbes Studies 27/1 (2014): 1-12.
} 


\subsection{The Subject of Civil Science}

Hobbes's epistemology was continuously reworked during the 1640s, along with the relatively fast development of his political thought. In particular, this work in progress entailed a reconfiguration of the problem of the subject of science at each step of the elaboration of his civil science. The main steps were The Elements of Law Natural and Politic (accomplished in 1640), the two editions of De cive (1641/42 and 1647), the English Leviathan (1651). Later on, in 1668, he published the Latin version of Leviathan and wrote Behemoth, an account of the English civil war which was not precisely a political treatise (it concerned history, the scientific status of which had always been problematic, also for Hobbes). I shall limit myself here to drawing a synchronic picture of the structural problem he had to challenge, by taking geometry as the model and the starting point of this research, as he was doing when - in the dedicatory letter to De cive - he claimed he would ground the domain of moral philosophy as successfully as "the Geometers" had been able to make within their "province" (OL II, 137).

Hobbes elaborated a materialist and constructivist conception of geometry, which postulated an ontological continuity between the names and principles of geometry, and the physical elements and causes of motion. In Hobbes's peculiar geometry, points, lines and surfaces were physical entities, just as imagination, speech and all the 'phantasms of mind' were physical effects of bodily motion (of light and sound). In short, the objects of geometry were as 'material' as any other natural phenomenon, with the difference that they were entirely under human control. ${ }^{13}$ And it is precisely starting from the basic assumption that the possibility to construct an object entails the possibility of knowing and controlling it (and both geometrical figures and the body politic are a human product), that Hobbes's epistemological innovation in civil science emerged and was later consolidated:

\footnotetext{
${ }^{13}$ On Hobbes's geometry see D. Jesseph, Squaring the Circle. The War between Hobbes and Wallis (Chicago University Press, 1999), and Id., "Galileo, Hobbes, and the Book of Nature," Perspectives on Science 12/2 (2004): 191-211.
} 
Geometry therefore is demonstrable, for the lines and figures from which we reason are drawn and described by ourselves; and civil philosophy is demonstrable because we make the commonwealth ourselves. (EW VII, 184)

Therefore civil science was, as geometry, not to be considered merely descriptive, but rather strongly prescriptive and in fact - at least in principle - productive of its own object. And here comes the big problem, because both geometrical and civil science require the principles, the definitions and the names on which they are based to be steady and, in a certain sense, immune from motion, while in Hobbes we have no metaphysical hook for this purpose.

As a matter of fact, this point of view, which civil science could produce in theory, only sovereign power could actually endorse and make last. As we learn from Hobbes, there is no more stable artificial body in his philosophy than a well built and ordered commonwealth. In effect, in order to exist, science needs not only a long term existence out of the state of nature, but also a particular enforcement by civil power: in short, a politics of science was needed. ${ }^{14}$ Hence for conjoint epistemological and political purposes Hobbes planned an artificial body, a great living machine which would be long-lasting (although not eternal, since Leviathan is still a "mortal god"), capable of producing perpetual-like effects, and in particular a foundation of science by means of an artificial soul, the sovereign, which - securing the Commonwealth - would politically ensure the stability of those 'principles and names' on which peace and science (i.e. philosophy) are ultimately grounded. Within a materialistic framework, only the functioning of such a machine could embody (i.e. make exist) Descartes's metaphysical subject of science and fulfil the purpose to ground scientific

\footnotetext{
${ }^{14}$ An epistemological-political perspective was first endorsed by S. Shapin and S. Shaffer in their highly controversial and original Leviathan and the Air-Pump: Hobbes, Boyle, and the Experimental Life (Princeton, NJ: Princeton University, 1985). Another stream of research, emblematic of which is Y. C. Zarka, La décision métaphysique de Hobbes: Conditions de la politique (Paris: Vrin, 1999), stresses the key epistemological function played by political theory in Hobbes's system. In fact Hobbes never provided a definitive solution to the problem of the relation between epistemology and politics. Keeping the two together was not only the main problem of Hobbes's "critical materialism" - see A. Pacchi, Convenzione e ipotesi nella formazione della filosofia naturale di Thomas Hobbes (Firenze: La Nuova Italia, 1965) -, or the mark of his "obsession with providing a unified theory of science" - see N. Malcolm, "Hobbes's Science of Politics and His Theory of Science," in Id., Aspects of Hobbes (Oxford University Press, 2002), 146-155: it was also a crucial factor of his tormented elaboration of the epistemology of civil science during the 1640s.
} 
research. $^{15}$

Thus Hobbes increasingly conceived the relation between civil science and power as a circular relation, in which politics had primacy. And the primacy of politics was soon extended to all the domains of philosophy, as it was politics that provided the material conditions for the possibility of science itself. ${ }^{16}$ Consistently with this epistemological purpose, Hobbes's research eventually generated a subject of science that was entirely dependent on the very power that could grant its own existence. According to the 'genealogy' he presented in Leviathan,

leisure is the mother of philosophy; and Commonwealth, the mother of peace and leisure. Where first were great and flourishing cities, there was first the study of philosophy. (EW III, 666)

The strategic role played by the subjects of science and of power is in fact part of a story that goes far beyond the boundaries of Hobbes's enterprise, a story that I am going to schematically picture through the permutations of a simple topological structure occurring in the works of Machiavelli, Descartes and Hobbes. Sketching these shifts will enable a better focus on Hobbes's epistemological contributions to the changing relationship between the subjects of science and power in the domain of civil science.

When in 1513 Machiavelli dedicated The Prince, the summa of his political science, to Lorenzo De' Medici (the grandson of the Magnificent), he was in a way - one might say anticipating Galilean relativity, and situating the subject of science within the interplay of the powers expressed by the different points of view:

\footnotetext{
${ }^{15}$ Furthermore, it could secure ethical praxis without recurring to the acrobatic performances of Descartes' provisional moral.

${ }^{16}$ Indeed, according to Hobbes's own doctrine, geometry, the queen of sciences, was also in danger, exposed as it was to all kinds of arbitrary power adhering to custom rather than to reason: "I doubt not, but if it had been a thing contrary to any man's right of dominion, or to the interest of men that have dominion, that the three angles of a triangle, should be equal to two angles of a square; that doctrine should have been, if not disputed, yet by the burning of all books of geometry, suppressed, as far as he whom it concerned was able" (EW III, 91).
} 
For just as those who draw landscapes place themselves down in the plain to consider the nature of mountains and high places and to consider the nature of low places place themselves high atop mountains, similarly, to know well the nature of peoples one needs to be prince, and to know well the nature of princes one needs to be of the people. $^{17}$

In Descartes's and Hobbes's times this multiplication of the points of view was not at all a consolidated value in natural philosophy, neither could it be in political philosophy, of course. As already explained, with his metaphysical move - the separation of res cogitans and res extensa - Descartes had saved the subject of science from motion. He had separated the neutral, external and universal point of view of the subject of natural science from the mechanical performance of God's clockwork creation, the universe. The price to pay for this solution was an ontological gap between the deterministic functioning of nature and the metaphysical liberty characterising human agency, a gap that in fact contaminated civil science itself.

On the one hand reason was the disembodied external, clear and distinct gaze of the subject of the science on 'natural motion', and on the other hand reason was - along with passions part of the causes of a partially autonomous 'human motion'. Yet in the second case reason was only partially accessible from the contingent point of view Descartes had assigned, in his Discourse, to a provisional moral: more precisely, no geometrical science of morality was possible for Descartes precisely because reason was - by definition - not accountable for in terms of mechanical motion, i.e. of science. Thus Descartes had sharply separated not only the objects, but also the subjects of natural and human philosophies, making of moral and political philosophy - forcedly concerned (also) with the transcendent liberty of res cogitans - a non-geometrical one.

\footnotetext{
${ }^{17}$ N. Machiavelli, The Prince, transl. H. C. Mansfield (The University of Chicago Press, 2010), 4.
} 
This lack of a universal place for the subject of civil science is evidenced by Descartes's own permutation of Machiavelli's scheme. It recurs in the advice Descartes offered in 1646 to the Princess Elizabeth of Bohemia, ${ }^{18}$ concerning precisely Machiavelli’s "préface" [sic] to The Prince. In his letter Descartes claimed he did not share Machiavelli's theory, and in particular the way political knowledge was to be 'drawn' according to the latter:

The pencil only represents things which are seen from afar, but the main reasons for the actions of Princes are circumstances so particular that, if one is not Prince himself [...], he cannot imagine. (AT IV, 492)

This was just like saying that political knowledge should not be considered a science precisely because its supposed subject could not be situated out of particular political circumstances, in order to look at them "from afar". As a result, Descartes had separated the neutral external universal point of view of the subject of natural science from the internal and contingent point of view of the politically effective subject of political science. It is clear that from Descartes's perspective science and power cannot reside in the same subject. This allows us to frame the problem as follows: as long as the subject of knowledge is in motion (as it happens in Machiavelli), the subject of science is not absolute and steady, but it actually can produce political effects in the conjuncture; if the subject of science is grounded on a still point of view external to the situation (as it happens in Descartes's natural philosophy), scientific knowledge is absolute and secured, but it is also neutralised and not effective anymore.

On this basis, it is possible to appreciate Hobbes's own permutation of the same structure. We find it at the outset of Behemoth, where the Cyclopic gaze of the sovereign subject of mechanical science lurks over both the realms of history (time) and of a geometrically conceived nature (place), as to garher them into the unified horizon of objectivity:

\footnotetext{
${ }^{18}$ In fact former princess: at the time in exile at The Hague in the Netherlands.
} 
A. If in time, as in place, there were degrees of high and low, I verily believe that the highest of time would be that which passed between 1640 and 1660. For he that thence, as from the Devil's Mountain, should have looked upon the world and observed the actions of men, especially in England, might have had a prospect of all kinds of injustice.

Although the historical moment might be passed, history - conceived as "the relation" of actions, causes etc. - appears here the lever that can artificially raise the subject to the height of a science of the past conjuncture, allowing for a sufficiently detached, 'panoramic' view on human actions:

B. I should be glad to behold that prospect [...]. I pray you set me, that could not see so well, upon the same mountain, by the relation of the actions you then saw, and of their causes, pretensions, justice, order, artifice, and event. (EW VI, 165)

In order to cope with Descartes's metaphysical dualism, not only was Hobbes betraying Galileo's principle of the relativity of natural motion, he was also radically contrasting Machiavelli's 'political epistemology' of human motion, i.e. history. Through a kind of demoniac pact, Hobbes eventually exchanged the local efficacy of a subject of knowledge in motion within history, for the universality of a subject of knowledge quite steady and - as far as possible - safe at the margins of historical and natural motion, on the devil's mountain. But for this pact there was, of course, a price to pay. Along the lines of his epistemological struggle against Descartes's metaphysical dualism, Hobbes's research eventually generated a subject of science that was entirely dependent on the power that could preserve its existence from the monstrous contingency of matter in motion. In effect, his project entailed the evocation, in the political field, of a much more powerful monster than the one to be challenged, the monster Hobbes called Leviathan, to the building and conservation of which all sciences (civil science included) had to contribute in order to protect their own existence 
against the destructive power of the multitude, i.e. the 'human matter' Hobbes's civil science was concerned with.

\subsection{The Object of Civil Science}

Hobbes had always been looking for a materialistic alternative to the Aristotelian model for the body politic, but he was never able to consistently deduce civil science from the epistemological principles of his physics, without incurring in the problems entailed by Descartes's dualist epistemological agenda. As a matter of fact, although mechanical science remained the unvaried horizon of Hobbes's political theory, it did not determine its actual shape. For this reason Leviathan, the final achievement of his scientia civilis, was born an epistemological monstrosity.

A large amount of ink has been devoted to the suggestive figure represented in Hobbes's Leviathan's frontispiece and, more seriously, to the study of its theoretical meaning, historical sources, and its significance within Hobbes's political theory. More recently the discussion has been extended to the whole of Hobbes's frontispieces, attracting a renovated interest on the rhetorical tools through which Hobbes intended to implement his political theory. ${ }^{19}$ It has been noticed that there is hardly a compatibility between the traditional trope of the body politic to which Hobbes often refers metaphorically, and the allegorical image represented in the frontispiece of Leviathan. The traditional body politic entails different functions for the different parts of the body politic, while the image (in particular the one in the manuscript copy addressed to Charles II) represents indistinct individuals forming one person. Yet it has rarely been noticed and explicitly thematised that the programmatic reference to an automaton Hobbes provides in the introduction - where he describes an

\footnotetext{
${ }^{19}$ The importance of Hobbes's use of frontispieces goes far beyond Leviathan, as examined in particular by H. Bredekamp, Thomas Hobbes' visuelle Strategien. Der Leviathan: Urbild des modernen Staates. Werkillustrationen und Portraits (Berlin: Akademie Verlag, 1999), and by Q. Skinner, Hobbes and Republican Liberty (Cambridge University Press, 2008). Both scholars point to display the strategic efficacy of the accurate iconographical work Hobbes carried on, by studying the sources and purposes of his "visual strategies". On Hobbes's innovative iconographical choice in Leviathan, see also N. Malcolm, "The Title Page of Leviathan, Seen in a Curious Perspective," in Id., Aspects of Hobbes (Oxford University Press, 2002).
} 
artificial man made of spring, wheels and strings - is clearly inconsistent with the theological and biological metaphors Hobbes scattered throughout the whole book and pictured in the frontispiece.

It is evident that Hobbes was looking for an alternative model to the Aristotelian 'organic' body politic, and it is quite clear that Hobbes's Leviathan aims at the mechanical model of a powerful automaton he derived from the imagery of his epoch, endowed with a consistent and uniform motion capable of defeating the ungovernable multiplicity of the natural bodies of the multitude. In this sense the development of Hobbes's civil science also seems to point to the progressive integration of the traditional organic model for the body politic into the new mechanical model. From this perspective, the contradiction between Hobbes's programmatic assumption of a mechanistic model, and his constant use of biological metaphors cannot be entirely explained in terms of the rhetorical aims of Leviathan; it rather casts doubt on the consistency of the whole of the mechanistic enterprise.

As a matter of fact Leviathan, the book, was not at all about mechanics, and yet mechanics was postulated as the background, the ultimate justification of the whole argument there presented: human natural individual bodies are not fit for collective life, their growth is disorderly, and therefore the collective body has to be an artificial one, whose mechanical motion would function, on the contrary, according to the alleged laws of (human) nature. Hobbes's horror for organic growth is quite evident when he invests Leviathan, the biblical monster he draws from the book of Job, with the epic task of fighting the multiple-headed monster representing the hubris of "the children of pride" ${ }^{20}$ :

To what disease in the natural body of man, I may exactly compare this irregularity of a commonwealth, I know not. But I have seen a man, that had another man growing out of his side, with a head, arms, breast, and stomach, of his own: if he had had another

\footnotetext{
${ }^{20}$ Leviathan "is king over all the children of pride" in the book of Job 41:34.
} 
man growing out of his other side, the comparison might then have been exact. [...] It is a contention with ambition, like that of Hercules with the monster Hydra, which having many heads, for every one that was vanquished, there grew up three. (EW III, 318-19; 338)

New heads of the hydra continuously and 'naturally' grow in the body politic, from the dangerous imitation of the exempla of some great men, who should be opposed by the sovereign at the outset (when they still are of little danger). It was since the earlier Elements of Law that Hobbes pointed to any internally growing body as a potentially cancerous one, capable of becoming "one body of rebellion". ${ }^{21}$ And in De cive's dedicatory letter he explicitly stressed that a 'geometrically organised' commonwealth could perfectly secure peace, exception made for the eventuality of conflicts "over space, due to the growth of the multitude [crescente hominum multitudine]" (OL II, 137-38). In short, any growth preventing the mechanical functioning-as-one of the body politic becomes a kind of 'internal enemy', a risk for the overarching aim of the monstrous automaton: its continuation at all costs, in order to grant "peace and leisure" and - last but not least - a stable ground for scientific research.

Hobbes is still alluding to the book of Job by also building the Leviathan/Behemoth antithesis to mythically represent in the political domain this struggle between the ordered motion of the machine and the disorderly growing matter of the multitude. ${ }^{22}$ In Behemoth Hobbes conceives the multitude as ontologically characterised by a kind of motion which is not indifferent to the "rules of just and unjust". In fact the multitude naturally tends - so to say to oppose the artificial motion of the body politic. Independently of its composition, it forgets all that has been learned: "The common people have been, and always will be, ignorant of their duty to the public [...]. If you think the late miseries have made them wiser, that will

\footnotetext{
${ }^{21}$ T. Hobbes, The Elements of Law Natural and Politic, ed. F. Tönnies (London, 1889), 175.

${ }^{22}$ This antithesis was explicitly stated by Hobbes when he ironically suggested to Bramhall, for those who would prepare a refutation of his Leviathan, "a fit Title for their Book, Behemoth against Leviathan" (EW V, 27).
} 
quickly be forgot, and then we shall be no wiser than we were" (EW VI, 212, italics added). And this tendency is precisely what exposes it to all kinds of propaganda from which intermediate bodies (i.e. "the unjust") can emerge and grow. ${ }^{23}$

Hobbes's remedy to this cancerous disease was a true pharmakon, an artificial countermonster endowed with mechanically regulated motion, capable of challenging disordered organic growth. The main weapon of this project was a political pedagogy based on the assumption that "it is impossible that the multitude should ever learn their duty, but from the pulpit and upon holidays" (EW VI, 213). ${ }^{24}$ On this ground Hobbes sketched his project of reformation of the Universities for educating the educators to the new science. Such a project entailed a conjoint political and epistemological decision about the monstrosity of matter (and of the multitude). More precisely, an epistemological decision was intended to allow to both define and dominate the political monstrosity of human nature itself, by re-inscribing it within the established geometrical order:

Suppose a woman gives birth to a deformed figure, and the law forbids killing a human being, the question arises whether the new-born is a human being. The question then is, what is a human being? No one doubts that the commonwealth will decide - and without taking account of the Aristotelian definition that Man is a rational Animal. [...] In all disputes on these topics [i.e. "ius, politia, et scientiae naturales"] individual citizens should obey the laws and decisions of their commonwealth. (OL II, 389) ${ }^{25}$

Human nature could be thus reduced to the laws of nature; which means here - in the last

\footnotetext{
${ }^{23}$ It is quite easy to imagine "what kind of men such a multitude of ignorant people were like to elect for their burgesses and knights of shires" (EW VI, 212).

${ }^{24}$ Here Hobbes is particular challenging the Presbyterians and the Catholic Church. In effect, the (counter)model of Hobbes's project was the Catholic Church, who occupied the universities, forming scholars who spread ChristianAristotelianism: "Out of the Universities, came all those preachers that taught the contrary. The Universities have been to this nation, as the wooden horse was to the Trojans" (EW VI, 213).

${ }^{25}$ T. Hobbes, On the Citizen, ed. R. Tuck (Cambridge University Press, 1998), 215.
} 
instance - to an 'artificial' order grounded on (if not established by) political power. ${ }^{26}$ Hobbes's epistemological move was, in fact, an ideological one, in which he might be said to have actually endorsed Descartes's completely unaware suggestion of a possible extension of the mechanistic approach to the new civil science. This suggestion we can recollect by reading further the above quoted letter to Mersenne, where, just after stating that "it is God who has laid down these laws [mathematical truths] in nature just as a King lays down laws in his Kingdom", Descartes appears to emblematically convey the implicit desire of the whole mechanistic enterprise:

They are all inborn in our minds [mentibus nostris ingenitae] just as a king would imprint his laws on the hearts of all his subjects if he had enough power to do so. (AT I,

In this light it appears that a 'disciplinary, ${ }^{27}$ production of subjects was not only Hobbes's political project, it was the very epistemology of early-modern mechanism that entailed as such - when metaphysically grounded - an entire political pedagogy.

\section{Conclusion: The Political Pedagogy of Mechanical Philosophy}

Seventeenth-century theory of matter in motion was an ideological battlefield, where a monstrous mechanical order as the antidote to the monstrous contingency of matter was generated, both in the natural and in the political domains. In a way, Hobbes's philosophy

\footnotetext{
${ }^{26}$ It is worth noting that Hobbes always conceived the sovereign as an 'arbiter', not the 'creator', of truth. It is through this conceptual distinction that Popkin maintains that - although Hobbes was not a sceptic - by "making the sovereign the political arbiter of truth" he laid "the groundwork for a much more dangerous scepticism", the one characterising "the new Orwellian state", based on technologies capable of shifting state power from the possibility of 'deciding' on truth to the capacity of 'creating' it. R. Popkin, "Hobbes and Scepticism," in History of Philosophy in the Making, ed. Linus J. Thro (Washington DC: University Press of America, 1982), 145.

${ }^{27}$ Hobbes is pictured by Foucault mainly as the theorist of territorial sovereignty. I concede that Hobbes's concern with movement opens to a more dynamic interpretation of his conception of the relationship between society and the state, yet I assume that his mechanistic opposition to growth prevents going so far as to detect a properly 'biopolitical' issue in the "(re)productive movement" he deals with in political theory, as interestingly argued by L.A. De Vries and J. Spieker, "Hobbes, War, Movement," Global Society 23:4 (2009): 470-74. Rather - by assuming the tripartite framework provided in M. Foucault, Security, Territory, Population (Basingstoke: Palgrave Macmillan, 2004), 10-11, 22 - Hobbes might be said to have developed a theory of disciplinary power.
} 
itself was an ideological battlefield where the materialist tradition struggled against the ethical and political implications of Descartes's dualistic metaphysics and epistemology. Descartes's passive conception of matter, entirely submitted to the laws of nature, entailed the reference to a supreme legislator and to a deductive science of the new mechanical cosmos. On the other hand, the understanding of matter as itself in motion could possibly have been compatible with a genuinely materialistic experimental ontology in which no ordered cosmos or divine legislator had to be presupposed. But the 'geometrical' conception of matter in motion elaborated by the new mechanical science was not fit for materialism: in fact it was essentially dualist, and it entailed considerable consequences in political theory as well.

In effect, Descartes's metaphysical separation of the subject of science from moving matter had made classical politics, based on individual agency and personal wisdom, impossible. As the universal subject of science had to abdicate to any power at all, any aristocratic political wisdom was in fact at the mercy of the blind self-preservation tendency characterising the multitude. The indispensability of a protective political power was definitively assumed, grounded both on the use of force and on a whole set of pedagogical tools. ${ }^{28}$ The monstrous image of the sovereign pictured in the frontispiece of Leviathan - much more including than representing the multitude as one - was thus intended to be a self-fulfilling prophecy: the imagined persona worked both as the overall ideological effect of a well established commonwealth and the actual cause of its correct functioning, when implemented through an effective political pedagogy. This virtuous circle marks the birth of the ideology of technocracy as a form of government, capable of securing to the subject of science the power over reality that the epistemology of the Galilean science did not allow in itself.

\footnotetext{
${ }^{28}$ On Hobbes's crucial concern with political education, see G. M. Vaughan, Behemoth Teaches Leviathan (Oxford: Lexington Books, 2002).
} 
From this perspective, rather than the failure of a political myth, ${ }^{29}$ Leviathan represents the success of a philosophical myth: the early-modern myth of an existing mechanical order of nature that the monstrous political machine should automatically reproduce in the political domain, where it imposes itself as the only clear and distinct possible alternative to a perpetual struggle between the different parts of the body politic. This philosophical myth made it possible to keep together in a single double-faced monster a lawful, deterministic conception of the motion of matter inscribed in the laws of nature, and the alleged independency and neutrality of the sovereign subject of the geometrical science.

In this sense my analysis suggests that in Hobbes's philosophy civil science - a branch of natural philosophy as it was imagined by seventeenth-century mechanical philosophy - was born fit to become a technical tool for state power (when the modern state - it is worth adding - did not exist yet). A conjoint analysis of Hobbes's epistemological and political agendas would thus contribute to explain early modern mechanical philosophy as an ideological response to the non-geometrical contingency of matter evidenced by the threatening experimental practices carried on during the first half of the seventeenth century both in the new Galilean science of nature and in the English Civil War. From this perspective, although starting from completely different metaphysical premises, Descartes and Hobbes appear to have made the same ideological move: they excluded both the experimental unpredictability and the epistemological relativity that haunted the new mechanical science since its beginning. Of the monstrous resistance to this project 'matter in motion' has been, in my narration, the symbol.

\footnotetext{
${ }^{29}$ According to Schmitt, Hobbes's "political myth" was a failure because it accepted the discrepancy between the inner and the outer faith of the citizens, a separation that entails a kind of 'neutrality' of the state power in front of individual values that would seed potential subversion. In short, Hobbes's rationalism would not be able to successfully found the state on the historical and cultural roots of a people, a failure well represented in his eyes by the failure of liberal democracies. See C. Schmitt, The Leviathan in the State Theory of Thomas Hobbes: Meaning and Failure of a Political Symbol (The University of Chicago Press, 2008).
} 
In fact, Hobbes never referred the expression 'laws of nature' to natural regularities,${ }^{30}$ but nevertheless, during the 1640 s his political theory became more and more grounded on a completely new understanding of human nature as entirely submitted to mechanical determinism. As a consequence, the only possible alternative to determinism became the reference to the transcendental liberty theorised by Descartes. Accepting this very alternative still means today either to accept metaphysical dualism, or, as Hobbes did, to reduce one to the two terms to the other. By charging Hobbes's mechanical philosophy with reductionism I am not claiming that materialism is reductionist in itself. On the contrary, I see Hobbes's specific form of mechanicism as an implicit reduction of materialism to the mirror of its apparent enemy: the mechanistic dualism systematised by Descartes. ${ }^{31}$ In fact neither the idealism of the free will nor deterministic materialism can escape the early modern alternative and its ideological consequences. It is in this sense that Hobbes's philosophy can be said to mirror Descartes's within the materialistic tradition, erasing from human matter the contingency that would disrupt the geometrical imagination which follows the exigencies of political representation.

Hobbes's was a fake materialism precisely because it took for a metaphysical truth what science was only imagining on the grounds of its epistemological exigencies, namely ontological determinism and the establishment - in principle - of the possibility of absolute geometrical knowledge. Yet there is much more - even in the political field - on which a materialist philosophy can draw today thanks to scientific research. But to discover a few bits of this complex matter, philosophy has to exit the entirely ideological point of view on 'matter in motion' established by early modern mechanics and its metaphysics: a point of view which was built precisely through the neutralisation of what in matter resisted - and still

\footnotetext{
${ }^{30}$ With the noteworthy exception of a quick reference to "the laws of refraction" in T. Hobbes, The Elements of Law Natural and Politic, II.8 (London: Simpkin, Marshall \& Co., 1889), 6.

${ }^{31}$ An opening towards this path of research is possibly represented by the admirable synthesis provided by C. Leijenhorst, "La causalité chez Hobbes et Descartes," in Hobbes, Descartes et la métaphysique, ed. D. Weber (Paris: Vrin, 2005), 11719.
} 
resists, of course - the (theological) patterns of representation dreamed by mechanical philosophers. This early-modern world picture affected the development of political theories and practices during the following centuries, and - as I would like to suggest here -, although its basic features have been attacked and destroyed at the level of the natural sciences, it still informs our approach to political theory and science. 